\title{
Diskreční pravomoc veřejné správy $v$ intencích české a zahraniční právní vědy a praxe*
}

\section{Discretionary Power of Public Administration in the Sphere of Czech and Foreign Legal Science and Practice}

\author{
Barbora Gonsiorová**
}

\begin{abstract}
Abstrakt
Aplikace diskrečni pravomoci, jehož produktem jest diskrečni rozhodnuti správniho orgánu, je nevybnutelným institutem éeského správního práva. Bylo by však mylné domnivat se, že se jedná o právni institut ryz̨e český. Je tomu právě naopak. Vyskytuje se i v mnoha zabranióních právních úpravách, a to jak angloamerických tak kontinentálnich. Jeho vnimání, výklad a aplikace se víak v zabraničnim pojetí mưže lišit. Pro účly predkládaného článku byly shromáždèny zabranični poznatky k problematice diskrečniho rozhodováni, keteré predstaviji jeho výchozi zamèreni a zároveñ prostredek ke zkoumáni jejïh použitelnosti v českém právním prostredí. Hlavnim účlem článku je prìtom získáni a prezentace nových poznatke ke problematice diskeréního rozhodování.
\end{abstract}

\section{Klíčová slova}

Diskrece; správni uváženi; diskrečni pravomoc; diskrečni rozhodováni; vlastnosti; odvolací správni orgán; správni rád.

\begin{abstract}
The application of discretionary power, the product of which is a discretionary decision of an administrative authority, is an inevitable institute of Czech administrative law. But it would be mistakenly to think, that this is a purely Czech law institute. The opposite is true. It also occurs in many foreign legal regulations, both Anglo-American and Continental. However, his perceptions, interpretations and application may differ in these foreign conceptions. For the purposes of this article, foreign knowledge were collected on the issue of discretionary decision-making, which represents its initial focus and at the same time a means of examining its applicability in the Caech legal environment. The main purpose of the article is to obtain and present new knowledge on the issue of discretionary decision-making.
\end{abstract}

Keywords

Discretion; Administrative Consideration; Discretionary Power; Discretionary Decision-making; Behaviour; Appeal Authority; Administrative Code.

\footnotetext{
* Příspěvek vznikl v rámci projektu „Vybrané aspekty správního uvážení a jeho přezkumu“ podpořeného grantem Interní grantové agentury Univerzity Palackého v Olomouci - SPP 917100319/31.

** JUDr. Barbora Gonsiorová, doktorandka, Katedra správního a finančního práva, Právnická fakulta, Univerzita Palackého v Olomouci / Ph.D. student, Department of Administrative and Financial Law, Faculty of Law, Palacký University in Olomouc, Czech Republic / E-mail: barboragonsior@email.cz / ORCID: 0000-0001-6587-628X
} 


\section{Úvod}

Výkon diskreční pravomoci je jedním ze způsobů realizace veřejné správy. V souvislosti s dynamickým vývojem lidské společnosti, na něj nestále reagující legislativu a její výklad, je pro zákonodárce téměř nemožné účinně a efektivně regulovat veškeré oblasti lidské činnosti. V intencích správního řízení „pokrýt všechny varianty rozhodováni.“" A to zejména $\mathrm{v}$ těch př́padech, kdy je zapotřebí určitý stupeň odbornosti správního orgánu, ale i „prǔ̌nosti, prizprisobivosti nastalým a těžko predvidatelným situacím $i$ z. blediska dìsledku zásabu. "2 $\mathrm{V}$ těchto prŕpadech zákonodárce povolává $\mathrm{k}$ aplikaci institut správního uvážení ${ }^{3}$ jehož účelem je odborná, efektivní a účinná právní regulace společenských vztahů. Samotné rozhodnutí správního orgánu přijaté s použitím uvážení, které tak můžeme nazývat rozhodnutím diskrečním, je jejím produktem. Přitom v žádném právním předpise není obsažena definice správního uvážení či pojmu diskreční pravomoc, který je ostatně obsažen i v názvu tohoto článku. Oproti tomu nepřeberné množství definic a výkladů můžeme nalézt v oblasti právně vědecké. Tak například podle Bažila „volným wvážením správniho orgánu se zpravidla rozumi tomuto orgánu zákonem založená volnost zuolit prù rèéni kon-

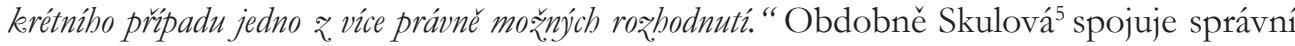
uvážení se situací, „kdy se vanikem nebo existenci určitých podminek nespojuje prǒslušné ustanoveni právního predpisu nutnost nastoupeni jedinébo možnébo právního následku, "ba naopak ponechává správnímu orgánu možnost volby řešení. Naproti tomu pojem diskreční pravomoc je třeba chápat šířeji. Opět dle Skulové ${ }^{6}$, se vedle klasického správního uvážení jedná o projev ,pravomoci toho, kdo roz̧hoduje tímto zpuisobem a je nositelem prǐslušné výseče veřejné moci. " Praktické definice $\mathrm{v}$ podobě rozhodnutí orgánů soudní soustavy lze přitom najít rovněž v hojné míre. ${ }^{7} J e n$ pro úplnost třeba dodat, že správní uvážení ani diskreční pravomoc nelze zaměňovat s neurčitými právními pojmy, nebot' tyto nepředstavují volbu mezi určitými možnostmi ani nejsou výrazem pravomoci takto volit, nýbrž toliko představujî pouze určitou interpretační činnost správního orgánu s ohledem na existující skutkový stav věci. ${ }^{8}$

1 HENDRYCH, Dušan a kol. Správní právo. Obecná část. 9. vyd. Praha: C. H. Beck, 2016, s. 55.

2 Ibid., s. 55.

3 „V žádném práunim predpise neni obsažena definice správníbo uváženi, je tedy nutno jej identifikovat ve fáz̨i interpretace a aplikace právni normy." Rozsudek Městského soudu v Praze ze dne 22. 8. 2012, sp. zn. 11 A 114/2011.

4 BAŽIL, Zdeněk. Neurčité právní pojmy a uvážení prí aplikaci norem správního práva: se zulástním žretelem na judikaturu bývalého čsl. nejvyššrího správního soudu. 1. vyd. Praha: Univerzita Karlova, 1993, s. 58.

5 SKULOVÁ, Soňa. Správni uvážení: qákladni charakteristika a souvislosti pojmu. 1. vyd. Brno: Masarykova univerzita, 2003, s. 15.

6 Ibid., s. 16.

7 Viz dále průběžně citovaná judikatura.

8 SLÁDEČEK, Vladimír. Obecné správní právo. 3. vyd. Praha: Wolters Kluwer, 2013, s. 145. 
Diskreční pravomoc ve smyslu správního uvážení však zdaleka není institutem vlastním pouze pro české správní právo. Vyskytuje se rovněž i v zahraničních právních úpravách, a i v těchto se lze setkat s mnoha snahami o jeho nejefektivnější výklad. Pohledem angloamerických autorů se jedná o tzv. administrative discretion. Institut určený odborníkům $\mathrm{k}$ výkladu obecných zásad práva a zákonů. ${ }^{9}$ Uplatňuje se tehdy, když zmocňující norma ponechává správnímu orgánu volnost zvolit si mezi možnými způsoby jednání nebo nečinnosti. ${ }^{10}$ Dále např́klad Sitorus ${ }^{11}$ popisuje diskreci jako ústřední a nevyhnutelnou koncepci sloužící k porozumění aplikace právních předpisů, kterými je diskrece vytvářena, ale na druhou stanu i omezována. Na nevyhnutelnosti použití institutu diskrece se shoduje i česká právní věda ${ }^{12}$ a praxe. Nelze než neupozornit na již legendární slova Vrchního soudu v Praze, který jednoznačně vyslovil, že „Rubem diskerečního oprárnèní správního orgánu je povinnost správního orgánu volné úvaby užit." ${ }^{13}$ Povinnost, ovšem ,podminèná účelností z. hlediska verejné správy. “14 Pohledem kontinentálního, konkrétně polského pojetí, je správní uvážení, neboli u乏nanie administracyjne, možností výběru následku správního aktu. Na samotné diskreční rozhodnutí lze přitom nahlížet jako na klasický projev výkonu impéria, tedy vrchnostenské správy zasahující do sféry práv a povinností adresátů, ale zároveň jako na výsledek určité volné tvůrčí činnosti správního orgánu. ${ }^{15}$

Je-li tedy institut správního uvážení institutem právně globálním, pak jeho význam a užití se v zahraničních právních úpravách může výrazně lišit od pojetí českého. Zájem právní vědy přitom záleží v analýze diskrece samotné v podmínkách její aplikace - tedy rozhodování. ${ }^{16}$ Mám za to, že by bylo na újmu české odborné diskuzi na téma diskrečního rozhodování, alespoň zčásti neshromáždit myšlenky, postřehy a závěry zahraničních autorů na toto téma. V následující výchozí kapitole bude nastíněno zahraniční pojetí problematiky 5ti typů, významů diskrečního rozhodování, kdy každý z nich má svůj jasný účel a funkci.

9 OLEJARSKI, M. Amanda. Administrative Discretion in Action. 1. vyd. Plymounth: Lexington Books, 2013, s. 21.

10 DAVIS, Kenneth. In: CLAYTON, Allen Scott. Judicial Review of Administrative Discretion. How Justice Scalia and Breyer Regulate the Regulators. 1. vyd. El Paso: LFB Scholarly Publishing LLC, 2015, s. 6.

11 SITORUS, Lily Evelina. Judicial Review of Administrative Action: Reflection on the Bank Century Bailout Policy. Indonesia Law Review [online]. 2016, č. 1 [cit. 3. 8. 2018]. Dostupné z: http://ilrev.ui.ac.id/ index.php/home/article/view/173/pdf_77

12 HENDRYCH, Dušan a kol. Správní právo. Obecná část. 6. vyd. Praha: C. H. Beck, 2006. s. 753. Cit. in EIDOVÁ, Lina. The Principle of Restricted Administrative Discretion. In: COFOL A 2010. Brno: Masarykova univerzita, 2010, s. 1701-1702.

13 Rozhodnutí Vrchního soudu v Praze ze dne 5. 11. 1993, sp. zn. 6 A 99/92.

14 MATES, Pavel. K povaze správních pořádkových deliktů. Právní praxe v podnikání [online]. 1995 [cit. 3. 8. 2018].

15 ZIMMERMANN, Jan. Prawo Administracyjne. 7. vyd. Warszawa: Wolters Kluwer, 2016, s. 395.

16 SITORUS, Lily Evelina. Judicial Review of Administrative Action: Reflection on the Bank Century Bailout Policy. Indonesia Law Review [online]. 2016, č. 1 [cit. 3. 8.2018]. Dostupné z: http://ilrev.ui.ac.id/ index.php/home/article/view/173/pdf_77 
Obsah tohoto článku tedy vychází ze získaných zahraničních poznatků k nastíněné problematice diskrečního rozhodování, která bude zkoumána skrze její použitelnost s pojetím českým. Rozhodováním, kde přichází v úvahu diskrece, se přitom s ohledem na české pojetí rozumí nejen klasické formální správní rozhodnutí ve smyslu ustanovení 9 zákona č. 500/2004 Sb., správní ráád ve znění pozdějších předpisů (dále jen „správní rád“), ${ }^{17}$ ale i jiné aktivní písemné či ústní úkony správních orgánů realizovaných na základě různých zákonů veřejnoprávního charakteru. Tyto úkony sice povahu formálního správního rozhodnutí nemají, avšak jejich vydání často předchází uvážení úřední osoby a pro adresáty vi̊či nimž tyto úkony směřují, vykazují vlastnost závaznosti. Adresáti jsou na jejich základě povinny určitým zpo̊sobem něco konat, něčeho se zdržet, či něco strpět. ${ }^{18}$ Proto na ně lze materiálně hledět rovněž jako na diskreční rozhodnutí. Dále, je-li předmětem zkoumání diskreční rozhodování, nemohu jej v tomto článku opomenout i jako výsledek jeho instančního vnitřního přezkumu. Nebot’ „správní ř̌zeni, stejně jako v nèm vydaná rozhodnuti orgánu pruního a drubého stupně, tvoř̀ vásadě jeden celek od zahájeni až do právni moci konečného rozhodnutí. "19 Hovoříme-li o odvolacím řízení jako o neskončeném řízení prvostupňovém, je zcela na místě, aby odvolací správní orgán sám správní uvážení aplikované v rozhodnutí orgánu prvního stupně korigoval, případně jej sám dotvořil. ${ }^{20}$ Má-li se tedy zkoumat diskreční rozhodnutí v intencích správního řízení, nelze jej nezahrnout v části řízení odvolacího. I v tomto směru bude české pojetí podrobeno srovnání s pojetím zahraničním, avšak již pouze kontinentálním - polským. Dưvodem jsou zcela rozdílné procesní právní úpravy angloamerických státu, pro něž by se jen stěží nacházela vhodná komparační forma. Jsem toho názoru, že pokus o komparaci pro účely „pouhého“ článku by vedl pouze k roztř́šstěným, neurčitým výsledkům. Naproti tomu komparaci s polským pojetím považuji za vhodnější, nebot' se v poměru k české právní úpravě jedná se úpravu odlišnou, avšak stále blízkou. Koncept hmotného i procesního práva je stejný, avšak při detailnějším zkoumání je možné zjistit, že pojetí jednotlivým institutů se v určitých rysech liší, a to nejen v právních předpisech je zakotvujících, nýbrž i pohledem právní vědy a judikatury. Pro účely zkoumání významně zasahující do práva procesního se tak polská právní úprava jeví jako ideální zdroj nových poznatků.

Podstatou tohoto článku je tedy, s ohledem na výše nastíněný obsah, prezentace získaných zahraničních poznatků $\mathrm{k}$ problematice diskrečního rozhodování. Přitom na tyto bude dále navázáno srovnáním s pojetím českým a následným zkoumáním jejich použitelnosti a souvisejících problematik v intencích české právní vědy a praxe. Účelem tohoto článku je, př̀ zachování výše uvedeného, získání nových poznatků k problematice diskrečního rozhodování.

\footnotetext{
17 Podle ustanovení \ 9 zákona č. 500/2004 Sb., správního řádu „Správní rízení je postup správního orgánu, jehož úcelem je vydáni roz̧hodnutí, jímž se v určité věci zakládají, mèni nebo ruši práva anebo povinnosti jmenovitě určené osoby...".

18 FRUMAROVÁ, Kateřina. Ochrana pred nečinnosti verejné správy. 1. vyd. Praha: Leges, 2012, s. $133-134$.

19 Rozsudek Nejvyššího správního soudu ze dne 27. 1. 2016, sp. zn. 6 As 24/2015.

20 Rozsudek Nejvyššího správního soudu ze dne 27. 1. 2016, sp. zn. 6 As 24/2015.
} 


\section{Vlastnosti a modely diskrečního rozhodování}

S přímým užitím pojmu diskreční rozhodnutí se můžeme setkat v odlišeném stanovisku ústavní soudkyně K. Šimáčkové k Usnesení pléna Ústavního soudu ze dne 7. 3. 2017. Jmenovaná ústavní soudkyně zde uvedla, že „tviorci Ústavy tak museli prì vqniku České republiky učnit rozhodnutí, keterá byla ve své podstatě diskerění, tj. nemèla jediné správné réšení. "21 Sluší se dodat, že K. Šimáčková hovořila o diskreci zákonodárce v otázce obsahu právní úpravy v mezích ústavního pořádku, ${ }^{22}$ nikoliv o diskreci správního orgánu.

$\mathrm{Na}$ druhou stranu s ohledem na pojetí diskrečních rozhodnutí správních orgánů má výše uvedený výrok Šimáčkové zásadní styčný bod. Je pravdou, že obsah právní úpravy je v jádru diskrecí zákonodárce. A je to právě zákonodárce, který sám určí, ve kterých případech bude diskreční rozhodnutí vydáno, a to zakotvením zmocňující normy. Slovy P. Matese „to, zda vỉbec bude použita a v jaké podobé, je záležitosti právnè politickou, ale zákonodárce by si mél uvédomit, že s výrazným praktickým dopadem. Žádné obecné pravidlo, které by stanovilo, kedy lze uváženi zakotvit, neexistuje. Nikedy by se v̌̌ak nemélo dít nahodile, ale na základě bedlivého posouzeni vhodnosti jeho zakotveni s obledem na nutnost zajištèni právni jistoty a jüních základnich práv občanu a rozboru podminek a potřeb úpravy daných společenských vatabư. "23 Tento právně vědecký názor Matese je stvrzen praxí Ústavního soudu, v jehož pojetí nikoliv nahodilost, nýbrž objektivnost, rozumnost a přiměřenost jest to, co by mělo zákonodárce vést $\mathrm{k}$ zakotvení diskreční pravomoci a tedy ,naplňováni veréjnébo zájmu v konkrétnich pröpadech diferencovanými postupy. "24

Existuje-li však již norma zmocňující k výkonu diskreční pravomoci, pak její samotný výkon může nabývat nejrůznějších podob. V angloamerických pramenech se lze často setkat s dílem Charlese H. Kocha, ${ }^{25}$ z něhož vychází i další autoři. Clayton ${ }^{26}$ s odkazem

21 Usnesení Ústavního soudu ze dne 7. 3. 2017, sp. zn. Pl. ÚS 34/16.

22 Úřad vlády České republiky. Legislativni helpdesk [online]. C2018 [cit. 11. 8. 2018]. Dostupné z: https:// help.odok.cz/vykladovy-slovnik/-/wiki/V\%C3\%BDkladov $\%$ C3\%BD $\% 20$ slovn $\%$ C3\%ADk/Diskrece

23 MATES, Pavel. Správní uvážení. In: Obecniportal.cz [online]. 25. 2.2013 [cit. 11.08. 2018]. Dostupné z: https://www.obecniportal.cz/33/spravni-uvazeni-uniqueidmRRWSbk196FNf8-jVUh4ElSFIyPgsnirjr4tfmlZRZA/

24 Usnesení Ústavního soudu ze dne 5. 8. 2009, sp. zn. I. ÚS 1354/09.

$25 \mathrm{KOCH}$, Charles H. Jr. Judicial Review of Administrative Discretion. William and Mary Law School Scholarship Reposity: Faculty Publications [online]. 1986 [cit. 11. 8. 2014]. Dostupné z: https://core.ac.uk/download/pdf/73971491.pdf

26 „There are as many as 5 types of discretionary actions taken on behalf of administrative agencies. These include, ,individualized discretion", „executing discretion", „policymaking discretion", „, unbridled discretion", and „numinous discretion". Koch explains the first three types are what courts typically review as they involve decisions such as adjusting the agency rules to fit a particular circumstance (individualized), filling-in gaps of ambiguous authorizing statutes (executing), and creating rules to further the aim or mission of the agency and authorizing statute (policymaking). Unbridled discretion refers to instances of discretion that the Courts are not allowed to review according to statute, and numinous discretion refers to acts of discretion which by its very nature is inaccessible to the courts. "CLAYTON, Allen Scott. Judicial Review of Administrative Discretion. How Justice Scalia and Breyer Regulate the Regulators. 1. vyd. El Paso: LFB Scholarly Publishing LLC, 2015, s. 5. 
na Kocha hovoří o pěti typech diskrečních činností správních orgánů. Sitorus ${ }^{27}$ naproti tomu, byt' rovněž s odkazem na Kocha, nehovoří o diskrečních typech, nýbrž o 5významech diskrece ve správním právu. Jedná konkrétně o:

- individualizační diskreci neboli volnost individualizace (individualized discretion), tj. přizpůsobení obecné právní úpravy konkrétním okolnostem případu;

- realizační diskreci (executing discretion), která zaplňuje prostor daný nejednoznačným zmocňujícím ustanovením;

- účelovou diskreci (policymaking discretion), která vytváří pravidla pro dosažení cíle předpokládaného věcnou působností rozhodujícího správního orgánu a předpisu, jehož je zmocňující norma součástí. Lze specifikovat též jako soulad diskrečního rozhodnutí s veřejným zájmem;

- nekontrolovanou diskreci (unbridled discretion), na kterou lze nahlížet dvěma způsoby. Primárně jako na diskreční rozhodnutí, která v důsledku opomenutí či nedbalosti zákonodárce nemohou být přezkoumána, nebot' z procesního hlediska neexistuje nadřízený správní orgán. Sekundárně jako na diskreční rozhodnutí, ježto jsou ze zákona vyloučeny z vnitřního instančního přezkumu;

- nezřetelnou diskreci (numinous discretion), zahrnující případy, kdy každá z možných variant rozhodnutí může, s ohledem na podstatu řešené otázky, být rozhodnutím správným.

Jak bylo uvedeno výše Koch a Clayton hovoří o typech diskrece, kdežto Sitorus o významech diskrece. Mým pohledem, je však možné na ně nahlížet rovněž i jako na požadavky kladené na tvưrčí činnost správního orgánu při tvorbě diskrečního rozhodnutí. ${ }^{28}$ A rovněž jako na vlastnosti, které by mělo „hotové“ diskreční rozhodnutí vykazovat. Zároveň však musím poukázat na jednu skutečnost. A to na Sitorem užité slovní spojení at least tedy „minimálně, nejméně“. Ano je samozřejmě možné se setkat s dalšími mnoha jinými výrazy popisující vlastnost diskrečního rozhodnutí, jako je např́klad efektivita, rozumnost, vhodnost použitého řešení atd. Na druhou stranu ovšem, vhodnou částečnou generalizací lze tyto výrazy zařadit $\mathrm{v}$ rámci výše uvedené systematiky.

Budeme-li na výše uvedené typy či významy diskrečního rozhodování nahlížet spíše jako na vlastnosti diskrečního rozhodnutí, mám za to, že je lze rozdělit do dvou modelů. Individualizace, realizace a účelovost jsou podle mého názoru vlastnosti, které nezbytně vykazuje každé zákonné a správné diskreční rozhodnutí Je tomu tak proto, že každé zákonné a správné diskreční rozhodnutí musí vycházet a zároveň reflektovat specifické okolnosti

27 „Discretion has at least 5 different meanings in administrative law." SITORUS, Lily Evelina. Judicial Review of Administrative Action: Reflection on the Bank Century Bailout Policy. Indonesia Law Review [online]. 2016, č. 1 [cit. 3. 8. 2018]. Dostupné z: http://ilrev.ui.ac.id/index.php/home/article/view/173/pdf_77

28 „Správni diskrece, neboli správni uvážení, je institutem správního práva, který umožñuje, aby správni orgány prú své rozhodovaci činnosti vycházely z konkétnich okolností danébo própadu, a vyhovovali tak požadavku individualizace správnich roz̧hodnuti." HENDRYCH, Dušan a kol. Správní právo. Obecná část. 6. vyd. Praha: C. H. Beck, 2006. s. 753. Cit. in EIDOVÁ, Lina. The Principle of Restricted Administrative Discretion. In: COFOLA 2010. Brno: Masarykova univerzita, 2010, s. 1701-1702. 
řešeného prrípadu, zaplnit prostor normou otevřený a odpovídat cílům a účelu věcně př́íslušné právní úpravy. Souhrnně je tedy lze podřadit pod obecně platný model diskrečního rozhodování. Avšak co se týče nekontrolovatelnosti a nežretelnosti, jedná se o vlastnosti, které ne každé diskreční rozhodnutí musí nezbytně vykazovat. V př́ipadě nekontrolovatelnosti se jedná o vlastnost, která se v závislosti na vưli zákonodárce může projevit v procesní rovině. Nadto se nedotýká roviny materiální, tj. zákonnosti a správnosti diskrečního rozhodnutí. Nežretelnost diskrece se oproti tomu roviny materiální dotýká, avšak zdaleka ne každá otázka, jež je předmětem diskrečního rozhodování, je ve své podstatě natolik subtilní, že na ni neexistuje jediná správná odpověd'. O nekontrolovatelnosti a nezretetelnosti lze tedy hovořit jako o modelu diskrečního rozhodování, který se vyskytuje v omezené mírée.

\section{Obecně platný model diskrečního rozhodování}

\subsection{Individualizační diskrece}

V Kochově ${ }^{29}$ pojetí se o individualizační diskreci hovoří jako o přizpůsobení právní úpravy konkrétním okolnostem řešeného prrípadu. $\mathrm{O}$ významu individualizace $\mathrm{v}$ diskrečních rozhodnutích nesporně svědčí skutečnost, že tato je zahrnuta v základních principech Doporučení výboru ministrů Rady Evropy č. 80 (2) o výkonu diskreční pravomoci správních orgánů. ${ }^{30} \mathrm{Na}$ druhou stranu individualizace je v podobě jedné z českých základních zásad činnosti správních orgánů nutně použitelná bez ohledu na to, zda se jedná o diskreční či nediskreční rozhodnutí. Slovy zákonodárce „Správní orgán dbá, aby prịjaté résení...odpovidalo okolnostem daného prǔpadu. “31 Je samozřejmou povinností správního orgánu tyto okolnosti v náležitém rozsahu a způsobem zjistit, ${ }^{32}$ tj. zjistit skutečnosti správné, úplné a relevantní. ${ }^{33} \mathrm{~V}$ oblasti diskrečního rozhodování pak tato povinnost obzvláště vystupuje do popředí, nebot' teprve od zjištěné skutkové situace se odráží možnost a zároveň povinnost volby řešení. ${ }^{34}$ Proto v procesu zjišt'ování relevantních skutečností zásadních pro vydání rozhodnutí, lze proto spatrovat zásadní předpoklad pro naplnění individualizační diskrece. Zejména pak v případech skutkově i právně složitých. Množina potenciálně dokazovaných okolností může být v takových prípadech

$29 \mathrm{KOCH}$, Charles H. Jr. Judicial Review of Administrative Discretion. William and Mary Law School Scholarship Reposity: Faculty Publications [online]. 1986 [cit. 11. 8. 2014]. Dostupné z: https://core.ac.uk/download/pdf/73971491.pdf

30 „An administrative authority, when exercising a discretionary power...observes objectivity and impartiality, taking into account only the factors relevant to the particular case." Doporučení Výboru ministrů Rady Evropy č. 80 (2) ze dne 11. 3. 1980.

31 Srov. ustanovení \ 2 odst. 4 správního řádu zakotvující zásadu individuálního posouzení každé věci.

32 Srov. ustanovení \3 správního rádu stanovující zásadu materiální pravdy.

33 Rozsudek Nejvyššího správního soudu ze dne 4. 10. 2017, sp. zn. 2 As 73/2017.

34 SKULOVÁ, Soňa. Správni uváženi: quákladni charakteristika a souvislosti pojmu. 1. vyd. Brno: Masarykova univerzita, 2003, s. 105. 
téměř „bezbřehá“. Je proto na úvaze správního orgánu, aby rozhodl, které skutečnosti je třeba dokazovat, a které nikoliv. Jinými slovy, aby rozhodl, které skutečnosti jsou pro daný př́ípad skutečně relevantní. Slovy praxe, jak uvedl stěžovatel v jedné z mnoha kasačních stížností řešených Nejvyšším správním soudem, „správní uváženi je podstatou individualizace rozhodovacího procesu. “35

$\mathrm{S}$ individualizací je však bezprostředně spjat i institut přiléhavé subsumpce. Přiléhavá subsumpce a na ní navazující volnost individualizace je klíčovým aspektem rozhodování správních orgánů demokratického právního státu. Opačný postup, tedy užití subsumpce bez možnosti individualizace, nemá v demokratickém právním systému své místo, nebot'

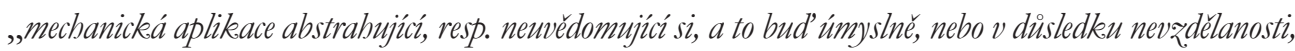
smysl a účl právni normy, čni z práva nástroj odcizeni a absurdity... Mechanické żtotožnèní práva s právními texty se stalo vitaným nástrojem totalitni manipulace. ${ }^{\text {'B6 }} \mathrm{Jak}$ vidno subsumpce je tak neodmyslitelnou součástí individualizace ${ }^{37}$ a i tato podléhá diskreci a jejímu náležitému zdůvodnění.

Je-li však s ohledem na citované ustanovení správního řádu individualizační diskrece podstatou všech správních rozhodnutí, jest zde rozdíl v individualizaci mezi výsledným rozhodnutím diskrečním a rozhodnutím nediskrečním? Mám za to, že ano a tento rozdíl lze spatřovat v postupu a požadavcích kladených na finální výstup správního orgánu v podobě vydaného rozhodnutí.

Je-li dle př́slušného právního předpisu úkolem správního orgánu vydat rozhodnutí, avšak bez zmocnění $\mathrm{k}$ diskreci, byt' např́klad za výkladu neurčitého právního pojmu, zde se volnost individualizace správního orgánu zaměřuje na danou skutkovou podstatu a její výklad. Při tomto postupu si správní orgán ujasní význam a účel neurčitého právního pojmu a vyhodnotí skutečnosti získané postupem a v souladu se zásadou materiální pravdy, tak by si objasnil, zda je lze zasadit do rámce předmětného neurčitého právního pojmu. „Musi tedy napr. zjïstit, zdali skutečně došlo ke porušeni veřejného porádku, a pokud ano postupovat tak, jako norma ukládá. "38

\section{Individualizace}
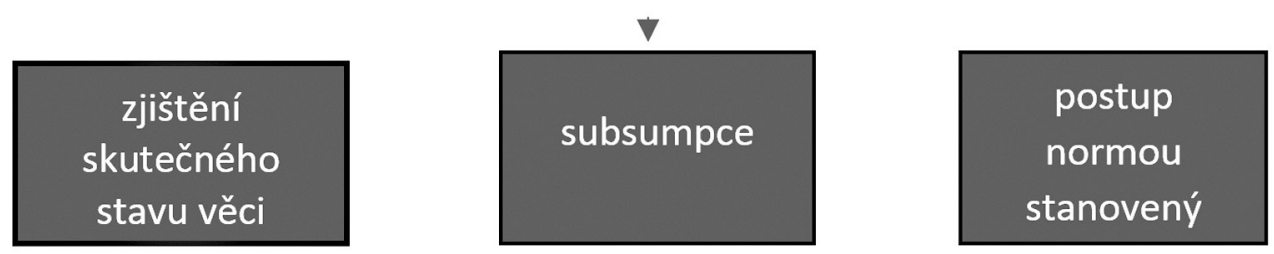

35 Viz Rozsudek Nejvyššího správního soudu ze dne 21. 5. 2015, sp. zn. 6 Azs 33/2014.

36 Nález Ústavního soudu ze dne 17. 12. 1997, sp. zn. Pl. ÚS 33/97.

37 Viz Rozsudek Nejvyššího správního soudu ze dne 22. 9. 2005, sp. zn. 6 As 57/2004: „Z této legislativnětechnické metody právni úpravy však v žádném pröpadě nelze dovozovat, že by se právni posouzeni skutkové stránky véci moblo obejít bez subsumpce pod jednotlivá ustanovení...."

38 HENDRYCH, Dušan a kol. Správní právo. Obecná část. 9. vyd. Praha: C. H. Beck, 2016, s. 55. 
Je-li však úkolem správního orgánu vydat diskreční rozhodnutí, je jeho volnost individualizace orientována rovněž na volbu, či způsob aplikace právního následku normou předpokládaného:

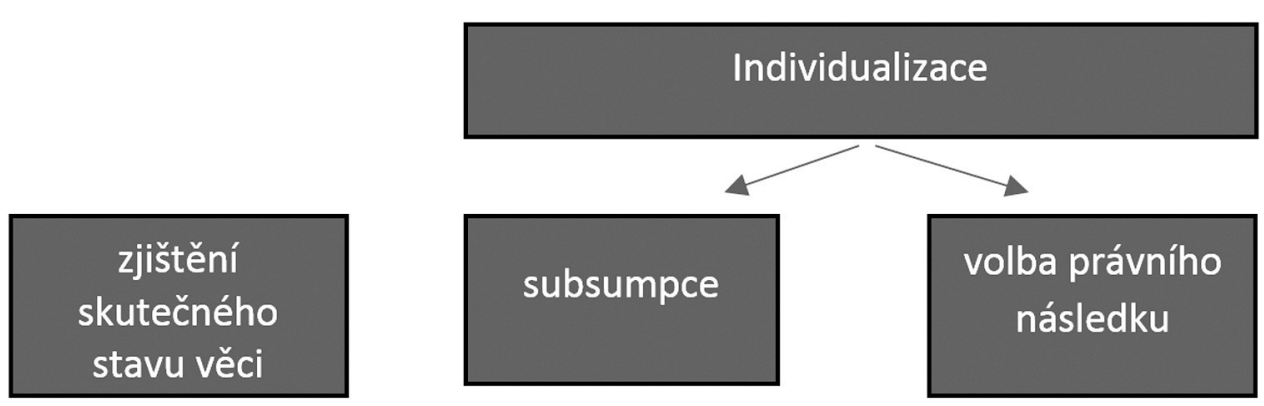

Z výše uvedeného a z demonstrativního zobrazení lze tedy dovodit, že individualizační diskreci se správní orgán nevyhne ani v prrípadech, kdy jeho výsledným produktem je rozhodnutí nediskreční. Rozdíl spočívá v její šíři a postupu správního orgánu, kdy v př́padech vydání rozhodnutí diskrečního se tato vztahuje i na samotné rozhodnutí.

\subsection{Realizační diskrece}

Vykonávací diskrecí jest myšleno zaplnění prostoru otevřeného zmocňující normou, a to pro konkrétní, individualizované diskreční rozhodnutí správního orgánu. Nutno však podotknout, že Koch $^{39}$ charakterizuje prostor daný zmocňující normou jako ambiguous tedy nejednoznačný. Nikoliv však prázdný. Diskreční rozhodnutí nikdy nezaplňuje prázdný prostor, takový ani nemůže $\mathrm{v}$ moderním právním státě existovat. Již Weyr ${ }^{40}$ $\mathrm{v}$ souvislosti s uplatněním diskreční pravomoci upozorňoval na to, že „aplikujicí orgán

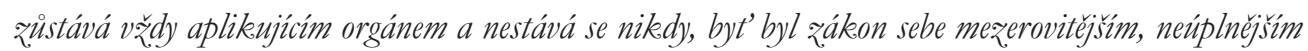
a obsahově sebe chudšim, normotvircem. "V intencích současného správního řízení s ohledem na zakotvení základních zásad činnosti správních orgánư ${ }^{41}$ a šíre jejich uplatnitelnosti ${ }^{42}$ pak vskutku nemůže být o prázdném prostoru řeč. Činnost veřejné správy je vždy, i při aplikaci diskreční pravomoci, činností pouze prováděcí v mezích zákona. Pouze v této intenci lze o realizační diskreci v českých podmínkách hovořit. Nikoliv jako o zaplnění, nýbrž provedení prostoru zákonem mu daného a zároveň zákonem omezeného.

$39 \mathrm{KOCH}$, Charles H. Jr. Judicial Review of Administrative Discretion. William and Mary Law School Scholarship Reposity: Faculty Publications [online]. 1986 [cit. 11. 8. 2014]. Dostupné z: https://core.ac.uk/download/pdf/73971491.pdf

40 WEYR, František. Ceskoslovenské právo správní. Cást obecná (Organisace verejné správy a ř́zeni správní. 1. vyd. Brno: Český akademický spolek „Právník“, 1922, s. 98.

41 Viz $\int 2$ až 8 správního řádu.

42 Viz $\int 177$ odst. 1 správního řádu, podle kterého „Základni quásady činnosti správních orgánů uvedené v 2 až 8

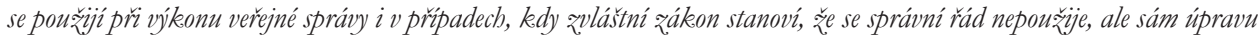
odpovidajici témto zásadám neobsabuje." 
S realizační diskrecí jsou však spojena určitá rizika, ježto, jak je ostatně rozvedeno níže, jsou riziky společnými jak v zahraničním tak českém právním prostředí. Tzv. discretionary power neboli diskreční pravomoc je možné na správní orgány delegovat za předpokladu, že zmocňující norma poskytuje dostatečně jasný standard k jejímu výkonu, který správní orgány vede a zároveň kontroluje při zjišt’ování konkrétních situací, na které je zákon aplikován. Zákonné normy jsou tak efektivně provedeny na základě těchto zjištěných skutečností a zároveň za stanovených podmínek, nikoli na základě rozmaru správních orgánů. ${ }^{43}$

Z výše uvedeného je patrné, že jednou s problematik, která je s realizační diskrecí spojena, je stanoveníjasných a zřejmých pravidel pro její výkon. Tj. zdali norma, která uděluje správním orgánům oprávnění $\mathrm{k}$ výkonu diskreční pravomoci, zároveň poskytuje tzv. rozumně jasný standard výkonu diskreční pravomoci. Podle Becka a Konar-Steenberga ${ }^{44}$ je otázka realizace diskrece úzce spjata s otázkou vágnosti vs. specifičnosti zmocňující normy. Dle jejich závěru př́liš vágní zmocňující norma vede k libovůli správních orgánů. Proto je ze strany zákonodárce nezbytné, aby zvolil konkrétnějšího jazyka, který zabrání excesivním výkonům diskreční pravomoci, čímž zároveň zajistí, že nastavená pravidla budou aplikována konzistentně. Tedy v opačném slova smyslu nespecifické a nejednoznačné pravidlo umožňuje správnímu orgánu vytvářet a naplňovat libovolná kritéria. Taková ad hoc tvorba pravidel ovšem není validní ${ }^{45}$ a v podstatě vytvář́ pole pro „ničm nevázané uplatňováni vile subjektu vykonávajicího správu. "46

Výše uvedené závěry angloamerických autorů k výkonu realizační diskrece v sobě tedy skýtají dva základní požadavky - konzistentnost a jasně nastavená pravidla zabraňující libovưli. Ona konzistentnost je v českém právním prostředí rovněž jedním ze základních limitů činnosti správních orgánů ${ }^{47}$ a zároveň ústavněprávním požadavkem na proporcionalitu ,ve bre vystupujicích práv a zájmü.“48

43 BECK, George a Mehmet KONAR-STEENBERG. Minnesota Administrative Procedure. Mitchell and Hamline School of Law [online]. 2014 [cit. 26. 08. 2018]. Dostupné z: https://mitchellhamline.edu/ minnesota-administrative-procedure/23-4-unbridled-discretion/

44 BECK, George a Mehmet KONAR-STEENBERG. Minnesota Administrative Procedure. Mitchell and Hamline School of Law [online]. 2014 [cit. 26. 08. 2018]. Dostupné z: https://mitchellhamline.edu/ minnesota-administrative-procedure/23-4-unbridled-discretion/

45 BERGIN, Kevin. Curbing „Unbridled Discretion“: The Direct and Indirect Effects of Patel vs. Los Angeles on Hotel Owners and their Patrons. Boston College Journal of Law and Social Justice [online]. 2015, č. 35 [cit. 11. 08. 2018]. Dostupné z: https://lawdigitalcommons.bc.edu/cgi/viewcontent. cgi? article $=1129 \&$ context $=j l s j$

46 SKULOVÁ, Soňa. Spráuni wvážení: qákeladní charakteristika a souvislosti pojmu. 1. vyd. Brno: Masarykova univerzita, 2003, s. 49.

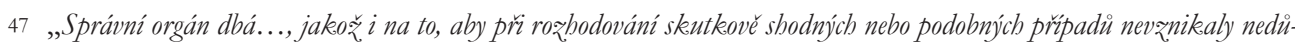
vodné rozdíly. "Viz ustanovení S 2 odst. 4 správního řádu postulující zásadu legitimního očekávání.

48 PRŮCHA, Petr. Správní rád s poznámkami a judikaturou. 3. vyd. Praha: Leges, 2017, s. 30. 
Nakolik prázdný je prostor daný zmocňující normou, je vưlí zákonodárce. V opačném slova smyslu je vưlí zákonodárce, nakolik tento prostor omezí. Na druhou stranu ani zákonodárci v tomto smyslu není umožněna libovůle. Regulace a její rozsah je zároveň jeho povinností, nebot' „zákon, který svèruje diskreční pravomoc, musi stanovit rozsah takové diskrece. " "A9 V oblasti právní vědy se můžeme setkat s rozčleněním až na tři stupně diskrece, tj. úplná (zákonná) vázanost, vázané uvážení, volné uvážení. ${ }^{50} \mathrm{Na}$ volné uvážení ve smyslu její absolutnosti lze přitom nahlížet i v tom smyslu, kdy neexistuje nárok, resp. subjektivní právo žadatele. $\mathrm{Na}$ druhou stranu i českou praxí jest judikováno, že diskrece není nikdy zcela neomezená, nebot' ,absolutní či neomeẓené spráuni uvážení v moderním právnim státě neexistuje. “51

Byt' je tedy zmocňující ustanovení jakkoliv nejasné či prázdné, zákonodárce v podobě zmocňujícího ustanovení nikdy nemůže správní orgány zmocnit k výkonu libovưle, nebot' ani on sám si nemůže počínat libovolně. Všichni adresáti právních norem, diskrečních obzvláště, jsou v souladu s principem právní jistoty oprávněni důvodně očekávat, že pravidla, které zákonodárce nastaví, jsou vyjádřeny přesně, jasně a srozumitelně a zároveň vykazují racionalitu a funkčnost ve vztahu k předmětné množině společenských vztahů, které mají býti těmito pravidly regulovány. ${ }^{52}$

$\mathrm{Na}$ druhou stranu i př́liš „těsná“ zákonná regulace sebou přináší nežádoucí důsledky v podobě politiky spočívající ve snaze o změnu právní regulace, ${ }^{53}$ jakmile se stávající právní úprava stane nevyhovující. Proto moderní cesta, kterou by se zákonodárce při konstrukci zmocňujícího ustanovení ubírat, by měla spočívat „v relativně abstraktním definováni podminek exekutivy. " ${ }^{54} \mathrm{Na}$ druhou stranu je ovšem nutno upozornit na praktickou stránku věci, a to na skutečnost, že kterákoliv norma zmocňující k diskreci vytváří určité riziko korupčního jednání. Tato okolnost však samozřejmě v převážné míre závisí na „významu“ předmětu správního řízení a jeho dopadu pro adresáty. Proto by zákonodárce při zachování výše uvedeného judikaturního doporučení spočívající v relativní abstraktnosti zmocňujících norem měl vždy poměřovat nutnost zmocnění $\mathrm{k}$ diskrečnímu oprávnění s mírou možného zásahu do individuální sféry subjektu, o jehož právech a povinnostech má být $\mathrm{v}$ rámci užité diskrece rozhodováno. Nastavená míra či rozsah diskrece by měla být vždy minimální, daná jen v nejnutnějším rozsahu.

49 Rozsudek ESLP ze dne 25. 3. 1983, Silver a dalši proti Spojenému království, č. j. 5947/72, 6205/73, 7052/7 $5,7061 / 75,7107 / 75,7113 / 75,7136 / 75$.

50 MATES, Pavel. Správni uváženi. 1. vyd. Plzeň: Aleš Čeněk, 2013, s. 87.

51 Rozsudek Nejvyššího správního soudu ze dne 23. 3. 2005, sp. zn. 6 A 25/2002.

52 Rozsudek Nejvyššího správního soudu ze dne 13. 5. 2004, sp. zn. 1 As 9/2003.

53 Viz Aktualizovaná důvodová zpráva k zákonu č. 204/2017 Sb., kterým se mění zákon č 256/2004 Sb., o podnikání na kapitálovém trhu, ve znění pozdějších předpisů, a další související zákony, změna zákona o podnikání na kapitálovém trhu a dalších zákonů.

54 Dále viz Rozsudek Nejvyššího správního soudu ze dne 27. 7. 2006, sp. zn. 2 Afs 207/2005: ... „V tomto smyslu żtráci svoji relevanci rozlišování roz̧hodováni exekutivy o ,nárocích" jednotlivcui a o ,nenárokových"právnich pozi-

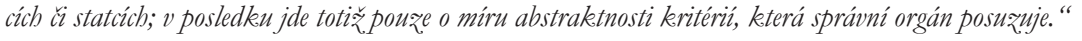




\section{3 Účelová diskrece}

Povinnost rozhodnutí v souladu se smyslem a podstatou zmocňující právní normy, nebo též v souladu s veřejným zájmem, je vlastnost diskrečního rozhodnutí a opětovně jedním z limitů rozhodování správních orgánů zakotvený skrze ustanovení \2 odst. 2 správního řádu. ${ }^{55} \mathrm{~S}$ ohledem na veřejný zájem šíreji v ustanovení $\ 2$ odst. 4 správního řádu. ${ }^{56}$

Byt' $\mathrm{k}$ tomu samotné slovo v originále znějící policymaking, tedy politizace, svádí, nejedná se v Kochově pojetí o prozařování politické moci do rozhodovací činnosti správních orgánů. ${ }^{57}$ Této však, s ohledem na správní orgány jako součást moci výkonné, nelze zabránit.

Požadavek, aby přijaté rozhodnutí bylo $\mathrm{v}$ souladu $\mathrm{s}$ veřejným zájmem, nutí $\mathrm{k}$ úvahám nad otázkou: A co oprávněné zájmy adresátů? Zejména jsou-li tyto v určité diferenci se zájmem veřejným. Pohledem polské právní vědy nemohu než upozornit na zajímavý postřeh Biłase ${ }^{58}$ hovořící právě o konfliktu veřejného a soukromého zájmu v rámci vydaného správního rozhodnutí vyplývajícího z čl. 7 Ustawy z dnia 14 czerwca 1960 r., Kodeks postępowania administracyjnego (dále jen „KPA“), který je polskou obdobou českého správního řádu. Tento článek praví, že „Správni orgány jsou povinny v pri̊běbu ř̌zeneni

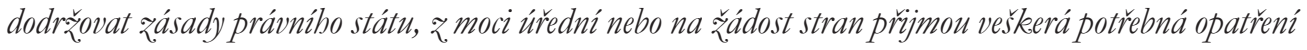
za úcelem dükladnébo objasnèni skutkového stavu věci a urovnáni véci, majic na žrételi veréjný zájem i oprávnèný zájem obřanu." ${ }^{59}$ Biłas ve vztahu k tomuto ustanovení hovoří o tom, že posláním aplikace diskrece je najít rovnováhu mezi zájmem veřejným a oprávněným zájmem adresáta.

Pohybujeme-li se v tendencích českého správního práva, je deklarace ochrany oprávněných zájmů občanů obsažena rovněž již ve správním řízení, a to prostřednictvím $\ 2$ odst. 3 správního ráádu, podle kterého „Správní orgán setrú práva nabytá v dobré viré, jakož.

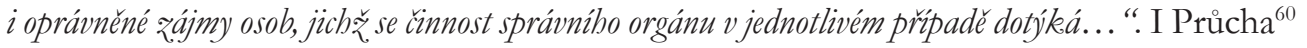

55 „Správni orgán uplatñuje svou pravomoc pouze ke tèm účelìm, ke nimž mu byla zákonem nebo na základě zákona svěrena, a v rozsabu, v jakém mu byla svěrena."

56 „Správni orgán dbá, aby prïjaté rè̃eni bylo v souladu s verejným zájmem a aby odpovidalo okolnostem daného prípadu, jakož i na to, aby pri rozhodováni skutkově shodných nebo podobných prīpadü nevznikaly nedivvodné rozdíly. "

57 Viz SYLVESTROVÁ, Tereza. Politizace justice, aneb jak ze soudce opět učinit subsumpční automat. In: Weyrovy dny právni teorie 2017. Brno: Masarykova univerzita, 2017, s. 123-130.

58 BIŁAS, Michał Jakub. Sądowa kontrola decyzji uznaniowych wydawanych przez organy administracji. Rocそnike Samorzqdowy [online]. 2015, č. 4 [cit. 11. 8. 2018]. Dostupné z: https://depot.ceon.pl/bitstream/handle/123456789/10215/Bi\%C5\%82as\%20 J.M.\%2c\%20S\%C4\%85dowa\%20kontrola \%20 decyzji $\% 20$ uznaniowych $\% 20$ wydawanych $\% 20$ przez $\% 20$ organy $\% 20$ administracji $\% 2 c \% 20$ Rocznik $^{0} 20$ Samorz $\%$ C4\%85dowy $\% 202015 \% 2 c \% 20$ t. $\% 204$.pdf? sequence $=1 \&$ is Allowed $=y$

59 „W toku postępowania organy administracji publicznej stoja na strą̇y praworzqdności, z. urzedu lub na wniosek stron podejmuja wszelkie caynności niezbedne do doktadnego wyjaśnienia stanu fak.tycznego oraz do zatatwienia sprawy, majac na wagledzie interes spoteczny i stuszny interes obywateli. "

60 PRŮCHA, Petr. Sprámí rád s poznámkami a judikaturou. 3. vyd. Praha: Leges, 2017, s. 30. 
v citovaném ustanovení \2 odst. 3 správního řádu poukazuje na nezbytnost vyváženosti mezi výkonem veřejné správy a omezením oprávněných zájmů dotčených osob, které je důsledkem ochrany veřejných zájmů, které mají ve veřejné správě „obecně hodnotově prednost."

A dále rovněž v př́ípadě možného soudního přezkumu, nebot' „ve správním soudnictví poskytuji soudy ochranu verejným subjektivnim práviom fyzických i právnických osob zpuisobem stanoveným tímto zákonem... ".61 Jaká je však hranice, co do hledání účelovosti diskrečního rozhodnutí s ohledem na veřejný zájem a oprávněným zájmem občanư?

Jak vidno cílem obojích modelů, tj. českého i polského, je hledání a najití rovnováhy mezi veřejným zájmem a oprávněným zájmem adresátů již v rámci vedeného správního rrízení, byt' jazyková vyjádření jsou odlišná. Co se týče hranice účelovosti diskrečního rozhodnutí ve vztahu $\mathrm{k}$ oprávněným zájmům adresátů, v českém modelu správního řízení je cílem správního orgánů najít řešení odpovídající veřejnému zájmu za současného zásahu do oprávněných zájmů subjektů ,jen za podminek stanovených zákonem a v nezbytném rozsahu. "62 Úkolem exekutivy je tedy nalezení řešení, které je v souladu s veřejným zájmem za současné eliminace případných zásahů do oprávněných zájmů adresátů. Rovnováha mezi těmito dvěma elementy by pak měla být nalezena již v řízení správním, a pokud tomu tak není, a dojde $\mathrm{k}$ neúměrnému zásahu, měly by k ochraně nastoupit správní soudy. Jinými slovy řečeno není-li rovnováha mezi veřejným zájmem a oprávněnými zájmy subjektů nastolena již výsledkem správního rrízení, resp. jsou-li oprávněné zájmy dotčeny, je úkolem soudů, aby na základě příslušného podnětu tuto nerovnováhu rozpoznal a napravil. Byt' se tedy s ohledem na hodnotovou přednost veřejného zájmu může zdát, že český model správního řízení poněkud upřednostňuje tento nad zájmem subjektů, není tomu tak. Výsledkem má být vždy nastolení určité rovnováhy.

\section{Model diskrečního rozhodování jako jev omezený}

\subsection{Nekontrolovatelná diskrece}

Nekontrolovatelnou diskrecí jest myšleno taková, která nemůže být přezkoumána nadřízeným správním orgánem. V oblasti procesního práva může objevit v důsledku dvou skutečností. Prvně v důsledku nepozornosti či nedbalosti zákonodárce, kterou došlo k absenci nadřízeného orgánu, který by diskreční rozhodnutí přezkoumal. ${ }^{63} \mathrm{~V}$ druhém př́padě se jedná o výslovný zákonný distanc přezkoumání.

61 Viz ustanovení \ 2 zákona č. 150/2002 Sb., soudní řád správní, ve znění pozdějších předpisů (dále jen „SŘS“).

62 Srov. ustanovení $\int 2$ odst. 3 správního řádu.

$63 \mathrm{KOCH}$, Charles H. Jr. Judicial Review of Administrative Discretion. William and Mary Law School Scholarship Reposity: Faculty Publications [online]. 1986 [cit. 11. 8. 2014]. Dostupné z: https://core.ac.uk/download/pdf/73971491.pdf 
Je ovšem pravdou, že $\operatorname{Koch}^{64} \mathrm{v}$ souvislosti s nekontrolovatelnou diskrecí odkazuje i na takové př́pady, kdy nepřezkoumatelná diskrece je spojena s takovými rozhodnutími, která jsou natolik triviální, že jejich kontrola není zamýšlena. Co do triviality správních rozhodnutí, je snad možné konstatovat, že české pojetí takové rozlišování správních rozhodnutí neakcentuje. Nahlížíme-li však na trivialitu v kontextu jejich předběžnosti či nezávaznosti, lze zde určitou spojitost s českým pojetím nalézt (viz níže).

Co se týče prvního typu nekontrolovatelné diskrece, tedy takových diskrečních rozhodnutí, která nejsou v důsledku opomenutí zákonodárce ve správním rízení přezkoumatelná, lze $\mathrm{v}$ českém pojetí tuto možnost téměř vyloučit. A to jak z hlediska skutečné dvojiinstančnosti řízení s komponenty, které $\mathrm{k}$ ní prúsluší, tj. účinku devolutivního a suspenzivního, tak z hlediska pouhé možnosti prvostupňové rozhodnutí „protestovat. "65 Z hlediska procesního postupu vskutku mohou nastat př́ípady, kdy účastník nemůže proti prvoinstančnímu rozhodnutí podat odvolání, nejedná se však o opomenutí zákonodárce, nýbrž o jeho úmysl, ${ }^{66}$ Ten může být vyjádřen jednak výslovně, např́klad v př́ipadě exekučních výzev ${ }^{67}$ které jsou svou povahou usnesením, tedy rozhodnutím, avšak instančně nepřezkoumatelným, avšak i konkludentně, např́ílad v př́padě rozhodnutí o zákazu shromáždění. ${ }^{68} \mathrm{~V}$ tomto př́padě zákonodárce zvolil možný opravný prostředek v podobě žaloby ke správnímu soudu, tato však není prostředkem instančního přezkumu. Výše zmíněná exekuční výzva však není svou povahou rozhodnutím, které by zasahovalo do práv a povinností adresátů, ani je nově deklarovalo. $Z$ tohoto úhlu pohledu lze v ní shledat rys triviality. $\mathrm{Na}$ druhou stranu je ovšem třeba pamatovat na skutečnost, že české exekuční správní íízení obsahuje zcela svébytný opravný prostředek, tj. námit$\mathrm{ky},{ }^{60} \mathrm{které} \mathrm{jsou} \mathrm{mj.} \mathrm{uplatnitelné} \mathrm{právě} \mathrm{v}$ těch př́padech, kdy nelze podat odvolání. $\mathrm{Z}$ uvedeného príkladu vyplývá, že české správní řízení je, alespoň v obecné rovině, zabezpečeno katalogem opravných prostředkủ, kdy při širíi jejich uplatnitelnosti, si lze jen stěží představit správní rozhodnutí, proti němuž by žádný z nich nepřipadal v úvahu, a to $\mathrm{v}$ důsledku opomenutí zákonodárce. Je totiž zřejmé, že zákonodárce toto riziko krajně eliminoval.

Nyní k problematice v Úvodu naznačených jiných aktivních úkonů správních orgánů, než jsou klasická správní rozhodnutí, pro které mohou i nemusí existovat zákonná

$64 \mathrm{KOCH}$, Charles H. Jr. Judicial Review of Administrative Discretion. William and Mary Law School Scholarship Reposity: Faculty Publications [online]. 1986 [cit. 11. 8. 2014]. Dostupné z: https://core.ac.uk/download/pdf/73971491.pdf

65 PRŮCHA, Petr. Spráuni rád s poznámkami a judikaturou. 3. vyd. Praha: Leges, 2017, s. 270.

66 Srov. ustanovení \81 odst. 1 správního řádu, podle kterého „Účastník můře proti rozbodnutí podat odvolání, pokud zákeon nestanovíjinak."

67 Viz ustanovení \109 správního rádu.

68 Srov. ustanovení $\mathbb{1 1}$ odst. 3 zákona č. 84/1990 Sb., o právu shromažd’ovacím, ve znění pozdějších předpisů.

69 Viz ustanovení \117 správního řádu. 
pravidla. Např́klad faktické pokyny, bezprostřední zásahy, zajišt’ovací úkony. ${ }^{70}$ Jsou-li pro ně nastavena zákonná pravidla, předpokládá se, že proti nim existují i opravné prostředky. ${ }^{71}$ Pomineme-li soudní ochranu, ${ }^{72}$ pak vhodným př́kladem jsou donucovací prostředky městských strážníků, o jejichž použití strážník rozhoduje diskrečně ,podle konkrétní situace tak, aby dosábl účlu sledovanébo zákrokem. "73 Bezesporu se jedná o určité diskreční rozhodnutí strážníka učiněné v oblasti veřejné správy, avšak př́islušný zákon zmocňující $\mathrm{k}$ této diskreci neupravuje možnost, jak se proti tomuto úkonu bránit. Na druhou stranu, samozřejmě vedle nejúčinnější ochrany soudní v podobě tzv. zásahové žaloby podle $\int 82$ a násl. soudního řádu správního, existují i další komplementární prostředky ochrany, byt' s nižší účinností a vynutitelností, jako např́iklad podnětu k Veřejnému ochránci práv.

Výše uvedenými př́klady lze tedy jednoznačně demonstrovat, že v českém pojetí lze vyloučit situaci, kdy možnost obrany ze strany adresáta by byla absentována v důsledku opomenutí zákonodárce či pouhé triviality správního rozhodnutí v nejširším slova smyslu.

\subsection{Nezřetelná diskrece}

Samotný Koch ${ }^{74}$ uvádí, že existuje pojetí diskrece, které je těžké definovat a ještě těžší odůvodnit. Přesto však existuje a zdá se být pro veřejnou správu nezbytné. Nezřetelné užití diskrece zahrnuje případy, kdy správní orgán musí zodpovědět neurčitou otázku v kontextu extrémní nejistoty. Soud provádějící přezkum takového diskrečního rozhodnutí, nemůže požadovat, aby rozhodnutí vydané na základě tohoto druhu diskrece bylo správné nebo dokonce $\mathrm{v}$ rámci určité tolerance možné či schopné správnosti. Tento druh diskrece nelze považovat za vyjádřený, aplikovaný či odvozený standard. Z tohoto důvodu Koch nazývá výkon takové diskreční pravomoci jako „nezřetelnýc a zároveň jako diskreci v pravém slova smyslu, tzv. discretion in strong sense.

Koch $^{75}$ zároveň předkládá, dle jeho závěru snad nejznámější př́íklad nezřetelné diskrece, a to případ arašídového másla řešený Ústavem pro kontrolu potravin a léčiv. Předmětem byla otázka, zda arašídové máslo by mělo obsahovat $87 \%$ nebo 90 \% arašídů. Jaké je správné procento arašídů v arašídovém másle? I přes to, že v předmětné věci bylo

70 FRUMAROVÁ, Kateřina. Ochrana préd nečinností veřejné správy. 1. vyd. Praha: Leges, 2012, s. 133.

71 Srov. Rozsudek Nejvyššího správního soudu ze dne 1. 12. 2004, sp. zn. 3 As 52/2003.

72 Viz Žaloba o ochraně proti před nezákonným zásahem, pokynem nebo donucením správního orgánu podle ustanovení \ 82 soudního řádu správního a násl.

73 Viz ustanovení \ 18 odst. 4 zákona č. 553/1991 Sb., o obecní policii, ve znění pozdějších předpisů.

$74 \mathrm{KOCH}$, Charles H. Jr. Judicial Review of Administrative Discretion. William and Mary Law School Scholarship Reposity: Faculty Publications [online]. 1986 [cit. 11. 8. 2014]. Dostupné z: https://core.ac.uk/download/pdf/73971491.pdf

$75 \mathrm{KOCH}$, Charles H. Jr. Judicial Review of Administrative Discretion. William and Mary Law School Scholarship Reposity: Faculty Publications [online]. 1986 [cit. 11. 8. 2014]. Dostupné z: https://core.ac.uk/download/pdf/73971491.pdf 
shromážděno více než 7.000 stran písemných podkladů v průběhu 9ti let trvání tohoto procesu, žádný ze shromážděných materiálů neukázal, že $87 \%$ arašídů je více či méně správné než $90 \%$. Z tohoto př́kladu vyplývá, že nezřetelná diskrece nastupuje v těch př́padech, kdy správní orgán rozhoduje otázku, na kterou, i přes pečlivé shromáždění všech dostupných podkladů, neexistuje jediná správná odpověd’. Nezřetelná diskrece je zahrnuta do mnoha diskrečních rozhodnutí a správní soud, který se při přezkumu takového rozhodnutí snaží do tohoto typu diskrece zasahovat, nejenže si usurpuje pravomoc správního orgánu, ale rovněž degraduje rozhodování správního orgánu zpơsobem, který nemůže kompenzovat.

Jak vidno Kochovo pojetí nezretelné diskrece v podstatě odpovídá slovům Kateřiny Šimáčkové hovořící o rozhodnutích zákonodárců, která nemají jediné správné řešení. ${ }^{\text {"76 }}$ Ono jediné správné řešení nemůže být nalezeno i přes náležité shromáždění všech potřebných podkladů. Jiným českým př́padem nezřetelné diskrece může být jmenování předsedy Úřadu pro dohled nad hospodařením politických stran a politických hnutí, ${ }^{77}$ a to konkrétně v př́padě, kdy oba kandidáti splňují zákonem stanovené podmínky. Nadto vykazují stejnou míru zkušeností, odborných i morálních kvalit. Výběr kandidátů je plně v diskreci prezidenta, ovšem jeho diskrece je diskrecí nezřetelnou, nebot' v okamžiku kdy více kandidátů splňuje zákonné podmínky pro jmenování, avšak jmenován může být pouze jeden, nemá jeho rozhodnutí jediné správné řešení.

Musím však poukázat na jednu skutečnost - otázka nezřetelnosti diskrece je i otázkou její správnosti. Byt' je tento rys diskrečního rozhodnutí ze své podstaty neprezkoumatelný, stále jsou možné jiné faktory diskrečního rozhodnutí, které přezkoumatelné být mohou. Hledíme-li na správnost v pojetí Skulové, ${ }^{78}$ tedy jako na efektivnost, rozumnost a účelnost použitého řešení, jedná se v podstatě o ty elementy, které jsou přezkoumatelné. Hledíme-li však na správnost ve smyslu podstaty otázky, která předmětem řešení v pojetí Kocha na tzv. core discretionary decision neboli jádro samotného diskrečního rozhodnutí, ve smyslu podstaty otázky, pak tato efektivně přezkoumána být nemůže, nebot' její podstata správné řešení nemá. S odkazem na definice obsažené v úvodu tohoto článku, v jádru se jedná spíše o uplatnění diskreční pravomoci v širším slova smyslu, tedy o výraz pravomoci takto rozhodnout. Nikoliv o diskreční pravomoc ve smyslu správního uvážení se všemi jeho komponenty.

76 Usnesení Ústavního soudu ze dne 7. 3. 2017, sp. zn. Pl. ÚS 34/16.

77 Viz ustanovení \19c odst. 1 zákona č. 424/1991 Sb., o sdružování v politických stranách a v politických hnutích, ve znění pozdějších předpisů, podle kterého „Předsedu Úřadu jmenuje a odvolává prezident republiky. Předsedu Úradu jmenuje prezident republiky ze dvou kandidátů, z nicȟ̌ jednoho navrbuje Poslanecká snèmovna a jednoho navrbuje Senát."

78 SKULOVÁ, Soňa. Ke kritériím soudního přezkumu správního uvážení (aneb poněkud disproporcionální úvaha nad dvěma soudními rozhodnutími. In: Dny práva - 2009 - Days of Law. Brno: Masarykova univerzita, 2009, s. 153. 
Ve smyslu výše uvedeného je tedy třeba na správnost nahlížet dvojím pohledem. Výše uvedené Kochovo pojetí je v českém právním systému v podstatě vtěleno ustanovením věty druhé $\int 78$ odst. 1 soudního řádu správního, ${ }^{79}$ které je provedeno bohatou judikatorní praxí, ${ }^{80}$ ježto se jednoznačně vyslovuje, tak že vskutku není úkolem soudu nahradit odbornost, kompetenci ani správní uvážení svým vlastním. Samožrejmě pomineme-li výjimku v podobě moderačního oprávnění soudu dle $\int 78$ odst. 2 soudního řádu správního vnášejícího prvek apelační, soudní přezkum správních rozhodnutí je systémem primárně kasačním, soudy tedy nemohou rozhodovat za správní orgán. ${ }^{81}$ Úkolem soudního přezkumu diskrečních rozhodnutí je, zda ze strany správního orgánu došlo k naplnění zásady materiální pravdy, náležité individualizaci, a zda nedošlo k excesu při výkonu diskrece a její politizace. Zkráceně řečeno nelze správní uvážení závislého orgánu nezávislým soudcovským uvážením. ${ }^{82}$

\section{Pokračování neskončeného prvostupňového řízení - diskreční rozhodnutí v intencích odvolacího správního orgánu}

Existuje-li tedy v právním řádu určitý institut, jehož užití je nevyhnutelné, avšak nikoliv bezproblémové, je třeba $\mathrm{k}$ němu přistupovat s nejvyšší obezřetností. Nadto je-li mj. úkolem vnitřního přezkumného orgánu jeho korekce, či př́ípadné dotvoření. ${ }^{83}$ Toto vymezení v podstatě naplňuje tezi o tom, že odvolací ř́izení je pokračováním neskončeného řízení prvostupňového. Český judikatorní pohled na povahu správního odvolacího řízení je souladně doplňován i pohledem polským, když podle Szota ${ }^{84}$ odvolací správní orgán opětovně meritorně rozhoduje o tomtéž. V tomto důsledku může sám zvolit nejvhodnější řešení. Tedy provést správní úvahu znovu. Odvolací správní orgán není nijak vázán rozhodnutím orgánu prvního stupně a v rámci svého rozhodování by si měl učinit vlastní úsudek. Tímto má zároveň možnost nahlédnutí do všech kritérií, kterými byl řízen orgán prvního stupně.

Je ovšem toto polské pojetí uplatnitelné i v podmínkách českých? Zejména za situace, kdy praktická podstata diskrečního rozhodnutí, tj. jeho správnost, není přezkoumávána

79 „Je-li žaloba dìvodná, soud zruši napadené roz̧bodnutí pro nezákonnost nebo pro vady rízení. Pro nezákonnost zruši soud napadené roz̧hodnutí $i$ tehdy, zjisti-li, že správni orgán prekeročil zákonem stanovené mezue správníbo uváženi nebo jej zneuřil."

80 Nejnověji viz Rozsudek Městského soudu v Praze ze dne 31. 1. 2018, sp. zn. 9 A 112/2015. Prejudikatura viz Rozsudek Nejvyššího správního soudu ze dne 18. 12. 2003, sp. zn. 5 A 139/2002.

81 Rozsudek Nejvyššího správního soudu ze dne 19. 5. 2009, sp. zn. 1 Azs 20/2009.

82 Viz Usnesení rozšířeného senátu Nejvyššího správního soudu ze dne 16. 11. 2016, sp. zn. 5 As 104/2013.

83 Rozsudek Nejvyššího správního soudu ze dne 27. 1. 2016, sp. zn. 6 As 24/2015.

84 SZOT, Adam. Słuszność a uznanie administracyjne. Studia Iuridica Lublinensia [online]. 2011, č. 15 [cit. 11. 8. 2014]. Dostupné z: http://bazhum.muzhp.pl/media/files/Studia_Iuridica_Lublinensia/Studia_ Iuridica_Lublinensia-r2011-t15/Studia_Iuridica_Lublinensia-r2011-t15-s175-182/Studia_Iuridica_Lublinensia-r2011-t15-s175-182.pdf 
automaticky, nýbrž až $\mathrm{v}$ důsledku zásahu odvolatele či požadavku veřejného zájmu. Není-li těmito vyvolán přezkum správnosti, nemá vnitřní přezkumný orgán možnost diskreci korigovat či dotvářet, nýbrž toliko pouze kontrolovat zákonný postup správního orgánu při přijímání prvostupňového diskrečního rozhodnutí. Skulováa ${ }^{85} \mathrm{v}$ této souvislosti uvádí, že kritérium správnosti otevírá dveře principům a zásadám. Pokud tedy přijmeme tezi, že rovněž správnost se pohybuje v rámci legality a má v ní oporu, zejména skrze základní zásady činnosti správních orgánů, rozdíl mezi přezkumem zákonnosti a správnosti nemusí být podstatný. ${ }^{86}$

Rozsah přezkumné pravomoci odvolacího správního orgánu je stanoven \89 odst. 2 správního řádu, přičemž skrze striktní jazykový výklad tohoto ustanovení se zdá, že odpovědnost za jeho realizaci je, zcela na odvolateli. ${ }^{87}$ Toto ustanovení správního řádu striktně vzato zavazuje odvolací správní orgán k povinnému přezkumu zákonnosti správního uvážení. Přezkum správnosti je odvislý od uplatněných námitek odvolatele nebo existenci veřejného zájmu na správném rozhodnutí. Není-li ani jedné z těchto podmínek, může tak teoreticky nastat situace, kdy diskreční rozhodnutí je sice zákonné avšak věcně nesprávné. To ovšem může být problematický aspekt, na nějž upozorňovala i S. Skulová: „Se zásadou dvoustupnovosti prezkumu uvnitř verejné správy byl spojen také jeji prínos spočivajici v možnosti odstranit pochybeni prvostupňového rozhodnuti uvnitř veréjné správy (zulástè, kdyžr. nebyl obecně dostupný soudni prezkum) a prezkoumávalo se ze zákona „v celém rozsahu“. U odvolání tradičně prïpadá v úvahu dokonce prezkoumáni týmž správním orgánem, pokud bude plně vyhovèno podanému odvoláni (autoremedura), tedy zde v zájmu účastnikea, a to pomèrně rychle. Vyhovèt odvolání bylo a je pak obecně možno také u odvolacího orgánu. Rovněž veřejný zájem bylo možno u odvolacíbo orgánu takto ochránit, pokud nebyla na prekéą̌ku zásada zákazu reformace in peius; současná úprava toto omezuje ještè podstatnèji, a to s obledem na práva a zájmy účastnikeì. Ti v̌̌ak musi být nyni bdèlejš́, neb plný princip apelačni již, neplatí, a „správnost“ by mèla být v jejich prospèch prezkoumána pouze v rozsabu námitek uvedených v odvolání. "88

Připustíme-li absenci námitek odvolatele směřující $\mathrm{k}$ věcné správnosti napadeného rozhodnutí, zbývá nám veřejný zájem, jako neurčitý právní pojem, jehož výkladu je třeba k posouzení odvolacího správního orgánu, zda přistoupí k přezkumu správnosti. Výklad

85 SKULOVÁ, Soňa. Správní uvážení: základní charakteristika a souvislosti pojmu. 1. vyd. Brno: Masarykova univerzita, 2003, s. 208.

86 SKULOVÁ, Soňa. Kolegiální orgány ve veřejné správě - V. Úvahy nad institutem rozkladu jako prostředku ochrany práv. Kniby VOP - Archiv knih VOP [ASPI]. 2013 [cit. 20. 8. 2014].

87 „Odvolaci správni orgán prezkoumává soulad napadenébo rozhodnuti a ř́zeni, které vydáni rozhodnuti predcházelo, s právnimi predpisy. Správnost napadenébo roz̧hodnuti prezkoumává jen v rozsabu námitek uvedených v odvolání, jinak

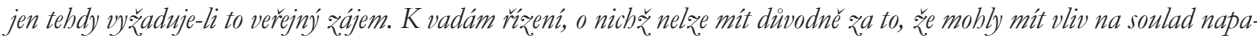
deného rozhodnuti s právnimi predpisy, poprīpadě na jeho správnost, se nepríhliží; tímto ustanovením neni dotčeno právo na nábradu škody zpuisobené nesprávným úredním postupem. "

88 SKULOVÁ, Soňa. Kolegiální orgány ve veřejné správě - V. Úvahy nad institutem rozkladu jako prostředku ochrany práv. Kniby VOP - Archiv knib VOP [ASPI]. 2013 [cit. 20. 8. 2014]. 
neurčitého právního pojmu, v daném prrípadě veřejného zájmu, je vždy individualizovaný. Jeho jednoznačný všeobecně platný výklad není možný, nebot' jak říká Nejvyšší správní soud ${ }^{89}$ „neurčité právní pojmy zahrnují jevy nebo skutečnosti, jejichž obsah a rozsah se může mènit, často bývá podminèn časem a mistem aplikace normy. "Na jednu stranu z takto podaného výkladu může plynout, že odpověd’ na otázku, ve kterých př́padech existuje veřejný zájem na správném rozhodnutí, neexistuje. Na druhou stranu, neměl by však v podstatě být vždy veřejný zájem na tom, aby rozhodnutí správního orgánu bylo nejen zákonné, ale i věcně správné?

Takové pojetí vnitřního přezkumu, zejména co se týče diskrečních rozhodnutí, vyvolává otázky o jeho vhodnosti. Oproti české, polská konstrukce odvolání je značně neformální, stojící na plném revizním principu. Rozsah přezkumné pravomoci polského odvolacího orgánu pramení z čl. 128 KPA. Dle tohoto ustanovení „Odvolání nevyžaduje podrobné odìvodnèní. Postač, je-li z odvoláni zrèjmé, že strana neni spokojená s vydaným roz̧odnutím. Zvlástni ustanoveni mohou stanovit dalši požadavky, pokud jde o obsah odvolání. "90 Polský zákonodárce tedy nevyžaduje uplatňování žádných námitek nesprávnosti a nenutí tak odvolatele k rozlišování toho, co považovat za kritéria zákonnosti, a co za kritéria správnosti. Na druhou stranu z jazykového výkladu předmětného článku není zcela zřejmé, jak by takové vyjádření nespokojenosti strany s vydaným rozhodnutím mělo vypadat. Zda by mělo obsahovat požadavek přezkumu rozhodnutí odvolacím orgánem a vydání odvolacího rozhodnutí podle čl. $138 \mathrm{KPA}^{91}$ nebo by mělo pouze vyjadřovat požadavek přehodnotit prŕpad vyřešený nedostatečným rozhodnutím? Je třeba vycházet z předpokladu, že odvolání jako opravný prostředek, by mělo prrinejmenším označit vydané rozhodnutí, nebot' je to prostredek pro nápravu vadných rozhodnutí, a nikoliv pouhá žádost o přezkoumání již vyřešeného př́ipadu. Polská doktrína vychází z pojetí předmětného ustanovení a uznává, že odvolání nemusí obsahovat žádné odůvodnění a dokonce ani to, do jaké míry či jakým směrem se odvolatel dožaduje změny rozhodnutí - odvolání je zcela neformálním opravným prostředkem, které má nespokojené straně maximálně usnadnit obranu jejích zájmů. ${ }^{92}$ Je tedy zcela na odvolateli, zda svou nespokojenost s vydaným rozhodnutím označí, zdůvodní, a případně v jakém směru. Na druhou stranu je však třeba poznamenat, z hlediska procesní taktiky odvolatele, že alespoň částečné zdůvodnění, může být v jeho zájmu, nebot' toto může pomoci odvolacímu orgánu v identifikaci vad napadeného rozhodnutí a tedy hledání pro něj příznivého rozhodnutí. ${ }^{93}$

89 Rozsudek Nejvyššího správního soudu ze dne 28. 7. 2005, sp. zn. 5 Afs 151/2004.

90 „Odwołanie nie mymaga szczegótowego uzasadnienia. Wystarçy, jeżeli zodwolania wynika, że strona nie jest zadowolona z. uydanej decyzji. Przepisy szczególne moga ustalać inne wymogi co do treści odwotania."

91 KNYSIAK-MOLCZYK, Hanna a kol. Kodeks postępowania administracyjnego. Komentarz. 1. vyd. Warszawa: Wolters Kluwer SA, 2016, s. 675.

92 Ibid., s. 674-675.

93 Ibid., s. 675. 
V opačném prípadě nese odvolatel riziko, že napadené rozhodnutí skutečně bude změněno či zrušeno, nicméně ne $\mathrm{v}$ pro něj příznivém světle, nebot' nedodal odvolacímu orgánu žádný podklad k určení, s čím přesně je nespokojen.

Vrátíme-li se zpět k rozsahu přezkumu českého odvolacího správního orgánu, pak toto se vskutku na první pohled povinně zaměruje na zákonnost. Avšak ani tato teze neplatí absolutně. Na tuto problematiku lze přitom nahlížet dvěma zposoby. Judikatorní pohled spočívá v tom, že je na účastníkovi řízení, jaký bude rozsah odvolacího přezkumu, „nebot’ jeho dispozici svèril, v jakém rozsahu a z jakých bledisek má být prvostupñové rozhodnuti prezkoumáváno. "94 Oproti tomu Průcha ${ }^{95}$ upozorňuje, že tuto problematiku nelze vnímat takto zjednodušeně, už jen s ohledem na to, že nesprávnost rozhodnutí může být ve své podstatě způsobem rozporem s právními předpisy. Zároveň rovněž upozorňuje na to, že každé správní řízení je v určité míře determinováno prosazením veřejného zájmu, spočívající v ochraně, která se promítá i do odvolacího řízení. To je konec konců pouhým pokračováním dosud neskončeného prvostupňového řízení.

S výše uvedeným závěrem se ztotožňuje i Jemelka, ${ }^{96}$ který uvádí, že problém rozlišování mezi zákonností a správností, vyvolávající pochybnosti odvolacího správního orgánu v otázce, co může přezkoumávat a co ne, spočívá v prŕlišně širokém pojetí základních zásad správního řízení. Ve smyslu již předchozí kapitole uvedeného, vlastnosti, které vykazuje správné správní uvážení, jsou efektivita, rozumnost, účelnost použitého řešení, apod. Srovnáme-li tyto vlastnosti správnosti volné úvahy s požadavky základních zásad správního řízení, je zřejmé, že tyto vlastnosti musí mít rozhodnutí, které je v souladu se základními zásadami.

Mohu tedy shrnout, že výsledkem přezkumného procesu odvolacího správního orgánu, při skutečně řádné aplikaci zákonných požadavků, nemůže být zákonné avšak věcně nesprávné rozhodnutí. Skrze základní zásady správního řízení je přezkum správnosti doslova vtažen do přezkumu zákonnosti a z pohledu odvolacího správního orgánu by tyto dva aspekty, tj. zákonnost a správnost měla splývat v jedno. Nelze tedy než říci, že \89 odst. 2 správního řádu, formálně omezující přezkumnou pravomoc odvolacího správního orgánu, ve světle základních zásad správního řízení postrádá smysl.

\section{Závěr}

Zkoumání zahraničního pojetí diskrečního rozhodování, nebylo úkolem snadným. Už jen z hlediska správného, přiléhavého jazykového překladu a vyhnutí se tak „,vytrhávání z kontextu“. Nicméně z obsahu článku a množství citovaných zahraničních vyplývá,

94 Rozsudek Nejvyššího správního soudu ze dne 13. 2. 2008, sp. zn. 2 As 56/2007.

95 PRŮCHA, Petr. Správní rád s poznámkami a judikaturou. 3. vyd. Praha: Leges, 2017, s. 291.

96 JEMELKA, Luboš, Klára PONDĚLÍČKOVÁ a David BOHADLO. Sprární rád. Komentár. 2. vyd. Praha: C. H. Beck, 2009, s. 353-354. 
že jestliže v českém právním prostředí je aplikace diskreční pravomoci ve smyslu správního uvážení jevem nevyhnutelných, nikoliv však bezproblémovým, ${ }^{97}$ taktéž je tomu i v zahraničních právních úpravách, a to jak zvolených angloamerických, tak v kontinentálním polském.

$\mathrm{V}$ případě prvostupňového diskrečního rozhodování, pro nějž byla stěžejní Kochova konstrukce 5ti typů diskrečního rozhodování, na které na které v tomto článku bylo nahlíženo jako na vlastnosti diskrečního rozhodnutí, lze konstatovat, že jejich výklad je, až na dílčí závěry, použitelný i v pojetí českém.

Individualizační diskrece je vlastností zcela nezbytnou pro samotný proces aplikace diskrece. Realizační diskrece neboli zaplnění prostoru otevřeného zmocňující normou, je oproti tomu vlastností „výslednou“, tj. takovou, kterou vykazuje hotové diskreční rozhodnutí. Na nepostradatelnosti obou těchto vlastností se shodují jak zahraniční tak české pojetí. V př́padě realizační diskrece nadto o společný problém jej sužující, a to otázka nastavení míry „otevřenosti“ zmocňující normy. Co do účelovosti diskrece jsme rovněž mohli spatřit shodu s pojetím polským. Obě směřují k totožnému výsledku v podobě nastolení rovnováhy mezi veřejným zájmem a oprávněnými zájmy subjektů. Toliko k modelu diskrečního rozhodování, který vykazuje obecnou platnost.

$\mathrm{K}$ druhému modelu diskrečního rozhodování, který se vyskytuje v omezené míře, tj. nekontrolovatelnosti a nezřetelnosti diskrece, zde byl zjištěn zásadní rozdíl. K nekontrolovatelné diskreci bylo řečeno, že tato se v Kochově pojetí vyskytuje v důsledku dvou rozdílných skutečností. V prvním případě v důsledku opomenutí zákonodárce a v druhém př́ipadě $\mathrm{v}$ důsledku zákonného distance. V příslušné části tohoto článku bylo jednoznačně vyvráceno, že opomenutí zákonodárce spočívající v nastavení instančního přezkumu je v českém pojetí krajně eliminováno. $\mathrm{V}$ tomto lze spatřovat jednoznačnou preciznost české právní úpravy oproti úpravě zahraniční. V souvislosti se zákonným distancem instančního přezkumu musím opětovně poukázat na slova K. Šimáčkové, použitá v částečně přeneseném významu - když zákonodárce něco stanoví, měl by vysvětlit proč tak učinil. ${ }^{98}$ Byl uveden př́klad zákonného distance v podobě rozhodnutí správního orgánu spočívající v zákazu shromáždění, proti němuž je opravným prostředkem žaloba ke správnímu soudu, ježto ale není instančním prostředkem obrany. Je však na škodu, že zákonodárce $\mathrm{v}$ důvodové zprávě $\mathrm{k}$ př́slušnému zákonu, ani slovem nezmiňuje, proč zvolil takovou konstrukci.

97 HENDRYCH, Dušan a kol. Spránni právo. Obecná část. 6. vyd. Praha: C. H. Beck, 2006. s. 753. Cit. in EIDOVÁ, Lina. The Principle of Restricted Administrative Discretion. In: COFOL A 2010. Brno: Masarykova univerzita, 2010, s. 1701-1702.

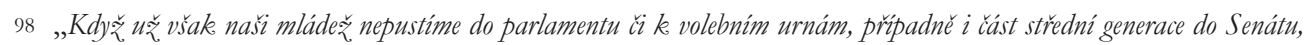
aspon̆ bychom jim mèli pořádně vysvétlit, že musí bledat jinou cestu než prostrédnictvím soudní litigace. "Viz odlišné stanovisko K. Šimáčkové k Usnesení Ústavního soudu ze dne 7. 3. 2017, sp. zn. Pl. ÚS 34/16. 
K možnosti doplnění či dotváření diskrečního rozhodnutí ze strany odvolacího správního orgánu, nezbývá než shrnout, že v českém pojetí se jedná o možnost odvolacího správního orgánu takto učinit s ohledem na jazykové znění příslušných ustanovení správního řádu. Z toho vyplývá, že odvolací správní orgán je omezen co do aktivity odvolatele. Oproti tomu na polské úpravě bylo demonstrováno, že takovému omezení odvolací správní orgán nepodléhá, což je zakotveno i v př́slušné právní úpravě. K analýze tohoto problému v intencích českého pojetí je dlužno konstatovat, že záleží na tom, jak formalisticky je zákonnost a správnost diskrečního rozhodnutí chápána. Mám ovšem za to, že byla jednoznačně vyvrácena teze, podle které je přezkum správnosti diskrečního rozhodnutí beznadějně vázán na uplatněné námitky odvolatele či dohledání veřejného zájmu na správném rozhodnutí. Respektive omezení je pouze formálního charakteru. Zakotvení základních zásad správního řízení v právním předpise, jejich formulace umožňující široký výklad a v neposlední řadě jejich všeobjímající závaznost pro správní orgány, prakticky materiálně stírá rozdíl mezi zákonností a správností použité diskrece, tím, že správnost se v podstatě stává součástí zákonnosti. A právě v tomto důsledku, se odvolací správní orgán vykonávající přezkum napadeného diskrečního rozhodnutí, i při absenci konkrétních námitek odvolatele a veřejného zájmu, nemůže přezkumu správnosti vyhnout. Slovy Skulové99 judikaturním vtažením obecných principů (ježto jsou v evropském správním prostoru nevyhnutelné) došlo k překonání klasicky, resp. formalisticky chápané zákonnosti. Možnost odvolacího správního orgánu, dotvořit či doplnit diskreci, tak aby již ve fázi správního řízení došlo k vydání nejen zákonného, ale i správného rozhodnutí, bez ohledu na aktivitu odvolatele, tak může být i v českém pojetí realizována.

Cílem tohoto článku byla prezentace zahraničního pojetí diskrečního rozhodování a zkoumání jeho použitelnosti ve srovnání s pojetím českým. Bylo přitom zjištěno, že zahraniční nazírání na problematiku diskrečního rozhodování se, až na výjimky, zásadním zpo̊sobem neliší od pojetí českého. Zároveň mám za to, že tento článek prínáší mnoho občerstvujících myšlenek a pojetí, které dosud nebyly v „domácím“ prostředí prezentovány, a na které mohou navázat další autoři. I to bylo nicméně účelem tvorby tohoto článku. Problematika diskrečních rozhodnutí bude diskutována, dokud tento institut správního uvážení bude sám v českém právním řádu existovat. A zapracování jiných, zahraničních pojetí, myšlenek a názorů může této diskuzi jen pomoct k tomu, aby taková diskuze neustrnula na opakované prezentaci již publikovaných závěrů, ba naopak se dynamicky vyvíjela, jako ostatně právo samotné.

99 SKULOVÁ, Soňa. Kolegiální orgány ve veřejné správě - V. Úvahy nad institutem rozkladu jako prostředku ochrany práv. Kniby VOP - Archiv knib VOP [online]. 2013 [cit. 20. 8. 2014]. 